\title{
The Analysis of the Use of Audiovisual Technology in Learning and Its Impact on Early Childhood Cognitive in Early Childhood Education of Percut Sei Tuan Sub-district
}

\author{
Ana Mulia ${ }^{1}$, Anita Yus ${ }^{2}$, Masganti Sitorus ${ }^{3}$ \\ ${ }^{1,2,3}$ Postgraduate Basic Education Study Program State University of Medan \\ Anamulia91@yahoo.com
}

\begin{abstract}
The use of audiovisual technology in learning can help educators deliver maximum learning material and create a pleasant learning atmosphere for children. This study is aimed to analyze the implementation of learning by using technology in early childhood education (PAUD) of Percut Sei Tuan sub-district and analyze the impact of the use of technology on early childhood cognitive in early childhood education of Percut Sei Tuan sub-district. This type of research uses descriptive research. The data analyzed are the results of observation, interviews and documentation. Samples taken in this study were obtained using purposive sampling technique. The data analysis stage is carried out namely data reduction, data classification, data presentation, and verification. The results showed that: Audiovisual technology in PAUD Percut Sei Tuan sub-district was still not fully used, from the overall indicators classified as in the sufficient category (36.3\%) with a lack of the use of interactive CDs and projector screens. PAUD Percut Sei Tuan Sub-district uses audiovisual technology such as computers, in focus, laptops and speakers to display learning applications, games, videos, films, Ms. Word, and Power Point which help teachers in delivering learning material and control the class so that they become more orderly and calm. Audiovisual technology has an impact on early childhood cognitive in PAUD Percut Sei Tuan Sub-district. Based on the overall indicators in PAUD, the average is in the good category (67.1\%), which includes indicators: reveal 4 objects based on their functions, reveal 4 differences from two objects, reveal the causal effects of 4 events, express 4 characteristics of objects based on color, size or shape, mentions 4 kinds of geometric shapes, and mentions 10 letters and 10 numbers with objects.
\end{abstract}

Keywords: Early childhood; cognitive; audiovisual technology.

\section{Introduction}

Early childhood education is very important because it coaching by educators in early childhood education (PAUD) institutions with various strategies, methods, media and approaches based on learning while playing will improve all aspects of child development.

In general, learning that is carried out in early childhood educational institutions both formal, informal and non-formal, there are still many obstacles, and challenges. In the past, learning was more traditional in nature and the use of learning strategies and methods that were not yet varied. In addition, learning tends to be centered on the teacher so that it does not provide opportunities for young children to be able to explore their potential freely. This is because there are still not optimal uses of technology that can be applied in PAUD learning in schools.

Technology is very useful in learning through the introduction of the form, purpose, and function of the technology media to students, because of the introduction, later children will be able to adapt to various kinds of audiovisual technology media tools. Introduction by using media can be done through audiovisual technology tools such as radio, television, laptops, in 
focus, speakers and computers, where the aim is to introduce functions, hazards and also their use (Khadijah, 2015).

Early childhood prefers simple visuals while older learners prefer complex ones, but simpler visuals are usually more effective. Early childhood are more likely to interpret the visual part by part than the whole, in conveying images of what they see, they might separate the specific elements that are visible (Sharon, et al., 2011).

Learning strategies used by educators when implementing learning activities in class must be in accordance with the learning styles of each child, one of which is a visual learning style. In making it easier for children to learn visually is to use visual material that is real objects or if it is not possible then may display such as pictures, cards, diagrams, and maps, as well as encourage children to use multimedia such as computers, videos, and television (Sit, 2012).

According to Jerome Bruner, children learn from concrete to abstract, like teaching about numbers. Numbers are symbols of numbers, so learn numbers from real objects first that need to be given before children learn numbers, therefore during the counting activity, children should be trained to count real objects first (Khadijah, 2016).

The development of instructional media currently follows the direction of technological development, so learning media are now using technology to deliver material or information in class. The technology that was used in the learning process is a printing press that works on the basis of mechanical principles. Then came audiovisual technology that combines mechanical and electronic for the purpose of learning (Seels \& Richey in Arsyad, 2009).

The use of technology as a medium for information delivery so that learning communication becomes multi-directional and not just one direction, that is, between teacher and student, so it is felt necessary in the context of teaching and learning activities. With a systematic and rational scientific approach, as demanded by this educational technology, effective and efficient educational goals will be achieved (Danim, 2010).

Learning can be meaningful if the student feels happy with what they are doing, so with that the researcher wants to see the extent of the use of instructional media from technology according to the description above, if the media is used properly and correctly according to its function, then the learning objectives can be achieved.

The use of technology that has 2 elements, namely hardware and software, or said to be from simple to sophisticated technology, must have extra tight supervision, so that the functions or benefits of using these tools can be carried out according to the rules correctly, and not just random, since starting to use technology media such as digital games, learning begins, in the sense that children are given direction so that they can understand and increase their knowledge.

Learning by utilizing technology in the classroom will change the mindset from teachercentered learning to student-centered learning, because the teacher's role in learning is as a facilitator to help student learn and develop all the potential that is owned by student.

Student will learn by one-way communication only (student to teacher) if the teacher is without aids or other learning media that are only as a messenger or information in class, thus making the learning atmosphere boring and children are less interested in actively participating in the learning. However, if the teacher as a facilitator uses instructional technology media will be able to make communication to be multi-directional (student to teacher and student to learning media) and not just one direction, so that changing the atmosphere of learning becomes fun for student. 
Learning using technology provides opportunities for teachers to be able to improve and develop their competencies, especially pedagogical competencies. The use of technology in learning is expected to be a solution in overcoming the problems of learning in the classroom caused by the suboptimal role of teachers in utilizing the use of technology in education, especially early childhood education.

One of the things that can be utilized by the world of education especially teachers in implementing the learning process is by using technology of PAUD learning in accordance with the level of child development. The use of technology properly is expected to be one of the alternatives in answering the challenges of PAUD learning in contemporary times while still prioritizing the principles of early childhood learning by paying attention to their characteristics and development.

PAUD institutions hopes that the use of technology can play a role in assisting teachers in implementing a learning process, especially to overcome the problem of lack of teaching aids. For this reason, a learning system is expected to be able to follow technological developments in an effort to improve the quality and education services in the future.

Good learning is carried out in this nowadays is where technology has become more sophisticated and on average all people from children to old people continue to use technological tools such as gadgets, laptops and others because these tools greatly facilitate their business and get what they want very easily and quickly. Therefore, educators today must take advantage of the rapid development of this era, not forbid children from using it because it cannot be ignored anymore indeed it has become their daily routine, just how an educator takes advantage of this opportunity in order to improve learning motivation in order to achieve optimal children's learning outcomes. Here is the importance of case studies in several schools that have supporting technology for learning tools or media which have a huge impact on the level of child development.

The use of audiovisual technology has an influence on various aspects of development in early childhood, one of which is on the children's cognitive development, this will further enhance the children's cognitive development achievements in each indicator in learning activities in class. The use of audiovisual technology in addition to simplifying the process of implementing learning and making learning more interesting also has an impact on aspects of cognitive development. Each child has different potential, so the task of educators is to be able to come up and hone the actual potential that exists in the child, so that the child's development, especially cognitive development, and help other aspects of development become optimal.

Cognitive levels possessed will affect other aspects of development. In cognitive, children learn to recognize symbols of numbers and letters, numerate, match according to their partners, recognize cause and effect, differences in size, color, shape, and others. These indicators are the basis of a children's brain development, which is able to open the way to make it easier to get other aspects of development, so that the process of growth and development in all aspects of development is optimal, and the children has a good level of cognitive achievement.

According to Jerome Bruner, children's learning process is started from concrete to abstract which occurs through three stages or modes determined by the way they look at the environment, one of which is iconic mode, that is, individuals understand their objects or their world through verbal images and visualization (Khadijah, 2016).

Human cognitive development is related to "the mental and physical ability to know certain objects, enter information into the mind, change existing knowledge with newly acquired information and are stages of thinking" (Sit, 2012: 76). 
According to Piaget, children development occurs in four stages, one of which is the preoperational stage (2-7 years). At this stage children begin to be able to do something as a result of imitating or observing a model of behavior and be able to do symbolization (Khadijah, 2016).

According to Bloom's Taxonomy, the cognitive domain is the ability of the workings of the brain. One of the lowest levels of ability in this domain is C1, knowledge. Knowledge is interpreted as a memory of things that have been learned before. And this ability is the beginning of the ability to know and convey memories (Khadijah, 2016: 133).

Based on some expert opinions above it can be concluded that cognitive ability is a stage in learning or thinking to understand the environment and use memory in simple problem solving skills.

According to Van Zyl in Iriantara (2014) stated several considerations that need to be taken when wanting to use the media for learning activities, there arw 1) The positive attitude of educators towards the use of media in learning, 2) Educators who want to use media, must know the advantages and disadvantages of each media, 3) Skills in operating media, 4) Availability of media devices in classrooms, and 5) Availability of required programs.

The teacher's role in using technology, media and materials. To do this, follow the "5P" process, preview technology, prepare the environment, prepare for learning and provide a learning experience (Sharon E. Smaldino, et al, 2011: 128).

According to Sutarman (2009) one of the positive impacts or advantages of using information and communication technology, which is to support and improve the quality of education (learning media). By utilizing computer technology we can improve the quality of education, such as by creating learning media for children, animations, or interesting simulations that will make it easier for children to accept learning.

Levie \& Lents states that visual media has a cognitive function, seen from the many scientific studies that suggest that visual symbols or images facilitate the achievement of goals to understand and remember the information or messages contained in pictures (Sutirman, 2013: 17).

\section{Research Methods}

This type of the study is descriptive research. Descriptive research intended in this study is an approach taken to analyze research data based on observations, interviews and documentation and use calculations that are presented in order to help produce more valid data.

This study presents information on the results of analysis in the form of identification of ways in which technology is used in learning by looking at its impact on early childhood cognitive. The location of this study was conducted at Early Childhood Education (PAUD) School in Percut Sei Tuan Sub-district, Deli Serdang District. The implementation of this study is planned to begin in April 2019.

The sample taken in this study was obtained by using purposive sampling technique that is choosing a place of research in accordance with the objectives of the researchers related to the title "the analysis of the use of technology in learning", so the sample in this study are 3 PAUD / TK which have audiovisual technology products and have an impact on Cognitive AUD consisting of IT Nurul Ilmi Kindergarten, Santa Lusia Kindergarten, and Salsabila KB (grade B aged of 5-6 years). This data collection technique used to obtain accurate and reliable data is observation, interview, and documentation. 
The data obtained in this study are descriptive data. Processing data through descriptive analysis, the data obtained will be used to describe the things examined in the results of research and discussion and are equipped with images obtained from the results of the documentation. Data were analyzed using the analysis technique of the Miles and Huberman models in Sugiono (2015). The data analysis stage is carried out namely data reduction, data classification, data presentation, and verification.

\section{Result and Discussion}

The results of this study will discuss the data relating to the use of technology in learning which includes: (1) the existence of audiovisual technology, (2) the process of implementing the use of audiovisual technology, (3) early childhood cognitive in learning activities.

Table 1. Observation Results of the Existence of Audiovisual Technology in PAUD Percut Sei Tuan Sub-district

\begin{tabular}{|c|c|c|c|c|c|c|c|c|c|c|}
\hline \multirow{2}{*}{ No } & \multirow{2}{*}{ Audiovisual Technology } & \multicolumn{3}{|c|}{$\begin{array}{c}\text { TK IT } \\
\text { Nurul Ilmi }\end{array}$} & \multicolumn{3}{|c|}{$\begin{array}{c}\text { TK Santa } \\
\text { Lusia } \\
\end{array}$} & \multicolumn{3}{|c|}{$\begin{array}{c}\text { KB } \\
\text { Salsabila } \\
\end{array}$} \\
\hline & & $\mathbf{1}$ & 2 & 3 & 1 & 2 & 3 & 1 & 2 & 3 \\
\hline 1. & Speaker & $\sqrt{ }$ & & & & & $\sqrt{ }$ & & $\sqrt{ }$ & \\
\hline 2. & Microphone & $\sqrt{ }$ & & & $\sqrt{ }$ & & & & $\sqrt{ }$ & \\
\hline 3. & Infocus & & & $\sqrt{ }$ & & & $\sqrt{ }$ & $\sqrt{ }$ & & \\
\hline 4. & Projector Screen & $\sqrt{ }$ & & & - & & & $\sqrt{ }$ & & \\
\hline 5. & Television & $\sqrt{ }$ & & & $\sqrt{ }$ & & & $\sqrt{ }$ & & \\
\hline 6. & The video & & & $\sqrt{ }$ & & & $\sqrt{ }$ & $\sqrt{ }$ & & \\
\hline 7. & Film & & & $\sqrt{ }$ & & & $\sqrt{ }$ & $\sqrt{ }$ & & \\
\hline 8. & Interactive CD & - & & & - & & & - & & \\
\hline 9. & The laptop & & & $\sqrt{ }$ & & & $\sqrt{ }$ & $\sqrt{ }$ & & \\
\hline 10. & Computer & - & & & & & $\sqrt{ }$ & - & & \\
\hline \multirow[t]{4}{*}{11.} & Power Point (PPT) & - & & & & & $\sqrt{ }$ & - & & \\
\hline & Total & 4 & - & 12 & 2 & - & 21 & 6 & 4 & - \\
\hline & Percentage (\%) & \multicolumn{3}{|c|}{$48,4 \%$} & \multicolumn{3}{|c|}{$69,6 \%$} & \multicolumn{3}{|c|}{$30,3 \%$} \\
\hline & Criteria & \multicolumn{3}{|c|}{ Sufficient } & \multicolumn{3}{|c|}{ Good } & \multicolumn{3}{|c|}{ Unsatisfied } \\
\hline
\end{tabular}

Technology is very useful in learning through the introduction of the form, purpose, and function of the technology media to students, because of the introduction, later children will be able to adapt to various kinds of audiovisual technology media tools. Introduction by using media can be done through audiovisual technology tools such as radio, television, laptops, in focus, speakers and computers (Khadijah, 2015). 
Based on the results of the study above, in the presence of audiovisual technology, an average are 3 schools studied all had audiovisual technology products such as television, in focus, speakers, and laptops, although not yet complete, but most of it is rarely used until it is broken.

IT Nurul Ilmi Kindergarten is classified as sufficient category (48.4\%) but in using audiovisual technology only once a month that is when the initiative of the teacher who at the time felt it was important and suitable to use such as film or video because according to their themes at that time added also so that children do not feel bored and bored.

In accordance with the opinion of the expert Van Zyl who stated that to use audiovisual technology media in learning activities need a positive attitude of educators towards the use of these media in learning, skills in operating the media, the availability of audiovisual technology media devices in the classroom, and the availability of the required programs (Iriantara , 2014).

Santa Lucia's kindergarten is also classified as a good category (69.6\%) in using audiovisual technology which is done every day that is Monday, Wednesday, Thursday, and Friday conducted in class, while Tuesday and Saturday are conducted in a computer laboratory room, which is divided into 2 groups: Tuesday for the Santa Maria class and Saturday for the Santo Fransiskus class.

According to Levie \& Lents, learning media especially visual media has several functions, one of which is the attention function, which is the image or animation media projected through LCD (Liquid Crystal Display) can focus and direct their attention to the learning they will receive. This affects the better mastery of learning materials by children (Sutirman, 2013: 16).

Whereas KB Salsabila (grade B aged of 5-6 years) is classified as unsatisfied category (30.3\%) because despite having audiovisual technology such as television, in focus, projector screens, speakers and microphones, the school does not use them in learning and is only used in only certain events.

So, based on the results of the research above, there is no such thing as a limitation of the provision of audiovisual technology from the school under study, but the school that wishes or does not use audiovisual technology in the era of today's sophisticated and modern, or just remains in the situation as before where learning focuses only on books and blackboards.

Table 2. Observation Result of the Implementation Process of Using Audiovisual Technology

\begin{tabular}{|c|c|c|c|c|c|c|c|}
\hline \multirow[t]{2}{*}{ No } & \multirow[t]{2}{*}{ Indicators } & \multicolumn{2}{|c|}{$\begin{array}{c}\text { TK IT } \\
\text { Nurul Ilmi }\end{array}$} & \multicolumn{2}{|c|}{$\begin{array}{l}\text { TK Santa } \\
\text { Lusia }\end{array}$} & \multicolumn{2}{|c|}{$\begin{array}{c}\text { KB } \\
\text { Salsabila }\end{array}$} \\
\hline & & Yes & No & Yes & No & Yes & No \\
\hline 1. & $\begin{array}{l}\text { Using the speaker or microphone } \\
\text { as a speaker when using visual } \\
\text { technology media }\end{array}$ & & $\sqrt{ }$ & $\sqrt{ }$ & & & $\sqrt{ }$ \\
\hline 2. & $\begin{array}{l}\text { Using the infocus to enlarge the } \\
\text { screen display }\end{array}$ & $\sqrt{ }$ & & $\sqrt{ }$ & & & $\sqrt{ }$ \\
\hline 3. & $\begin{array}{l}\text { Using the projector screen as a } \\
\text { display target of infocus to make it } \\
\text { look clearer }\end{array}$ & & $\sqrt{ }$ & & $\sqrt{ }$ & & $\sqrt{ }$ \\
\hline 4. & Using learning videos in class & $\sqrt{ }$ & & $\sqrt{ }$ & & & $\sqrt{ }$ \\
\hline
\end{tabular}




\begin{tabular}{|c|c|c|c|c|c|c|c|}
\hline 5. & $\begin{array}{l}\text { Watching a short film related to } \\
\text { learning material in class }\end{array}$ & $\sqrt{ }$ & & $\sqrt{ }$ & & & $\sqrt{ }$ \\
\hline 6. & $\begin{array}{l}\text { Using a laptop or computer in class } \\
\text { learning }\end{array}$ & $\sqrt{ }$ & & $\sqrt{ }$ & & & $\sqrt{ }$ \\
\hline 7. & $\begin{array}{l}\text { Using power points accompanied } \\
\text { by loudspeakers }\end{array}$ & & $\sqrt{ }$ & & $\sqrt{ }$ & & $\sqrt{ }$ \\
\hline 8. & $\begin{array}{l}\text { Using an interactive CD with a } \\
\text { laptop or computer with a speaker }\end{array}$ & & $\sqrt{ }$ & & $\sqrt{ }$ & & $\sqrt{ }$ \\
\hline 9. & $\begin{array}{l}\text { Using learning films or videos } \\
\text { once a week }\end{array}$ & & $\sqrt{ }$ & $\sqrt{ }$ & & & $\sqrt{ }$ \\
\hline 10. & $\begin{array}{l}\text { There is communication (asking } \\
\text { questions or expressing opinions) } \\
\text { between the child and the teacher } \\
\text { during the screening of the } \\
\text { learning film or video }\end{array}$ & & $\sqrt{ }$ & $\sqrt{ }$ & & & $\sqrt{ }$ \\
\hline 11. & $\begin{array}{l}\text { Feedback to children after } \\
\text { completion of video playback }\end{array}$ & & $\sqrt{ }$ & $\sqrt{ }$ & & & $\sqrt{ }$ \\
\hline & Total & 4 & 7 & 8 & 3 & - & 11 \\
\hline & Precentage $(\%)$ & \multicolumn{2}{|c|}{$36,3 \%$} & \multicolumn{2}{|c|}{$72,7 \%$} & \multicolumn{2}{|c|}{$0 \%$} \\
\hline & Criteria & \multicolumn{2}{|c|}{ Sufficient } & \multicolumn{2}{|c|}{ Good } & \multicolumn{2}{|c|}{ Unsatisfied } \\
\hline
\end{tabular}

The development of technology that is able to process, package and display and disseminate learning information both audio, visual, audio-visual and even multimedia, has now been able to realize what is called virtual learning (Darmawan, 2016). This concept developed so that it was able to package the settings and reality of previous learning to be more interesting and provide conditions psychologically adaptive to learning wherever located.

The use of audiovisual technology in learning can better control the situation of learning in the classroom. This can increase children's interest in focusing more on the material delivered by the teacher in front of the class and making the child more focused (shown in figures 4.7, 4.8. 4.9, 4.11).

Based on the results of research from 3 schools, it was found that no one has or used an interactive CD in learning, because the school still uses sticky media that is on the wall (letters, numbers, and hijaiyah) with different methods that are characteristic their school and brought every morning after praying and singing. In addition to the interactive CD which is quite expensive, it is also a bit difficult to do every day because it takes a long time to install, so it is better for schools to use their own methods to carry out early learning in the morning.

IT Nurul Ilmi Kindergarten is classified as sufficient category $(36.3 \%)$ in the aspect of using audiovisual technology in learning. How to use it which is brought from the office to the classroom and its installation is assisted by office staff. Learning by using in focus to watch videos or films is only used once a month. And as long as it is used there has not been any communication (asking questions or expressing opinions) between the student and the teacher during the screening of the film or video, as well as feedback to student who are still not visible.

Santa Lusia Kindergarten is classified as good category $(72.7 \%)$ in the aspect of using audiovisual technology in learning. Based on the three schools that became the research 
sample, only this school received a very good category in this aspect. With all the complete audiovisual technology available except interactive CDs and projector screens (using a large white board) and also teachers who have the ability to use IT are also accompanied by computer teachers, and coupled with audiovisual technology equipment that is installed permanently in each class, making learning using audiovisual technology easy to implement every day.

KB Salsabila (grade B aged of 5-6 years) is classified as unsatisfied $(0 \%)$ because it has not used audiovisual technology in classroom learning, even though the school has provided the media but there is no desire from the school to always use it in the classroom. After being interviewed directly to the class teacher about why they have not used this audiovisual technology media, and the answer is because the school basically only runs the calistung programs (read, write, count) which is the demands of the students' parents so that their children can read, write, and counting after graduating from the school.

Kemp (1980) argues that audiovisuals have a contribution to learning, and anyone who plans and uses audiovisual material should not only recognize the broad contribution of audiovisual in learning, but actively use audiovisual material to be useful in making a learning program, which will make education more productive through increased learning by providing valuable experiences for children that teachers do not need, or cannot, provide.

Based on the results of interviews that the school uses audiovisual technology media (films, in focus, speakers, projector screens, and laptops) only when there is a study or certain event that is once a year, and even then on the grounds that the children do not disturb parents when the event takes place.

Table 3. Result of Cognitive Observation in Learning Activities

\begin{tabular}{|c|l|c|c|c|}
\hline No & \multicolumn{1}{|c|}{ Indicator } & $\begin{array}{c}\text { TK IT } \\
\text { Nurul Ilmi }\end{array}$ & $\begin{array}{c}\text { TK Santa } \\
\text { Lusia }\end{array}$ & $\begin{array}{c}\text { KB } \\
\text { Salsabila }\end{array}$ \\
\hline 1. & $\begin{array}{l}\text { Reveal 4 objects based on } \\
\text { their function }\end{array}$ & $51,3 \%$ & $68 \%$ & $31,5 \%$ \\
\hline 2. & $\begin{array}{l}\text { Reveal 4 differences } \\
\text { between two objects }\end{array}$ & $68 \%$ & $47,2 \%$ & $50 \%$ \\
\hline 3. & $\begin{array}{l}\text { Reveal the cause and effect } \\
\text { of 4 events }\end{array}$ & $51,3 \%$ & $80,5 \%$ & $65,7 \%$ \\
\hline 4. & $\begin{array}{l}\text { Reveal 4 characteristics of } \\
\text { objects based on color, size, } \\
\text { or shape }\end{array}$ & $76,3 \%$ & $75 \%$ & $61,8 \%$ \\
\hline 5. & $\begin{array}{l}\text { Mention 4 kinds of } \\
\text { geometric shapes }\end{array}$ & $77,7 \%$ & $66,6 \%$ & $75 \%$ \\
\hline 6. & $\begin{array}{l}\text { Mention 10 letters and 10 } \\
\text { numbers with objects }\end{array}$ & $93 \%$ & $94,4 \%$ & $75 \%$ \\
\hline & Total & $\mathbf{4 1 7 , 6 \%}$ & $\mathbf{4 3 1 , 7 \%}$ & $\mathbf{3 5 9 \%}$ \\
\hline & Average & $\mathbf{6 9 , 6 \%}$ & $\mathbf{7 1 , 9 \%}$ & $\mathbf{5 9 , 8} \%$ \\
\hline & Criteria & $\mathbf{G o o d}$ & Good & Sufficient \\
\hline
\end{tabular}

Cognitive early childhood is directed at auditory and visual development. Auditory development is the development of early childhood abilities in listening through the process of receiving a collection of sounds of objects, vocabulary or sentences that have meaning in a 
particular topic. Visual development of early childhood is an ability related to vision, observation, attention, response, and perception of the child to the surrounding environment, including knowing objects by size, shape, or color, knowing objects that are missing from pictures, and recognizing letters and numbers (Khadijah, 2016).

Based on observations, it was found that there were two schools sampled in this study belonging to the good category and one other school that was classified as sufficient category, namely IT Nurul Ilmi Kindergarten School (69.6\%), Santa Lusia Kindergarten (71.9\%), and KB Salsabila (grade B aged of 5-6 years) (59.8\%).

IT Nurul Ilmi Kindergarten has a percentage result as an impact on childhood's cognitive development (good category 69.6\%). The results achieved are a good impact on childhood's cognitive, because from the results of observations the researchers found that each learning activity in the school always makes children feel the direct learning experience with children's science activities that are carried out every day and the themes that are running at the time, also explained by the teacher accompanied by a picture posted on the blackboard, after that the child was invited to complete the task in the form of children's work.

Santa Lucia's Kindergarten had a percentage result as an impact on childhood's cognitive (good category $71.9 \%$ ). The results achieved are a good impact on childhood's cognitive, because from the results of observations researchers found that every learning activity in the school almost always uses audiovisual technology. But at the beginning of learning the teacher found obstacles that the child did not recognize the letters of the alphabet, so to use a computer keyboard for children needed extra guidance. This should be the role of the computer teacher so that he can help the classroom teacher introduce the alphabet letters to children so that children can memorize these letters more quickly.

KB Salsabila (grade B aged of 5-6 years) has a percentage result as an impact on childhood's cognitive (sufficient category 59.8\%). The results achieved are a sufficient impact on children's cognitive, because from the results of observations researchers found that every learning activity in the school almost always emphasizes learning in reading, writing, and counting every day. However, based on observations, when entering the theme which at that time was the theme of My Country, the teachers have not provided an introduction to the theme, for example a picture of the Indonesian island, the symbol of the state (Garuda) and so on, so that when children are confronted with the picture shown by researchers, they look confused and need more explanation about the picture.

The use of audiovisual technology that is rarely done is not a benchmark that the childhood's cognitive is also less improved, but through explanations to children accompanied by pictures on the classroom walls, or with the presence of direct scientific activity, the child's cognitive also increases.

So, audiovisual technology is not a tool to improve childhood's cognitive, but only as a supporting medium for teachers to be able to deliver learning materials or better learning experiences so that children's cognitive becomes optimal.

\section{Conclusion}

Based on the results of research and discussion that has been presented, it can be concluded that audiovisual technology in PAUD Percut Sei Tuan Sub-district is still not fully used. Based on the overall indicators in PAUD, it is classified as sufficient category $(36.3 \%)$ with a lack of the use of interactive CDs and projector screens. PAUD Percut Sei Tuan Sub- 
district uses audiovisual technology such as computers, in focus, laptops and speakers to display learning applications, games, videos, films, Ms. Word, and Power Point which help teachers in delivering learning material and control the class so that they become more orderly and calm. During the use of audiovisual technology there is still communication (asking or expressing opinions) between the student and the teacher during the screening of the film or video, as well as feedback to the student.

Audiovisual technology has an impact on early childhood cognitive in PAUD Percut Sei Tuan Sub-district. Based on the overall indicators in PAUD, the average is in the good category $(67.1 \%)$, which includes indicators: reveal 4 objects based on their functions, reveal 4 differences from two objects, reveal the causal effects of 4 events, express 4 characteristics of objects based on color, size or shape, mentions 4 kinds of geometric shapes, and mentions 10 letters and 10 numbers with objects. Learning activities supported by audiovisual technology such as applications in the form of games and video learning in schools that have an impact on children's cognitive.

\section{References}

Arsyad, Azhar. 2009. Media Pembelajaran. Jakarta: Rajawali Pers.

Danim, Sudarwan. 2010. Media Komunikasi Pendidikan (Pelayanan Profesional Pembelajaran dan Mutu Hasil Belajar. Jakarta: Bumi Aksara.

Darmawan, Deni. 2016. Mobile Learning: Sebuah Aplikasi Teknologi Pembelajaran. Jakarta: Rajawali Pers.

Iriantara, Yosal. 2014. Komunikasi Pembelajaran (Interaksi Komunikatif dan Edukatif dalam Kelas. Bandung: Simbiosa Rekatama Media.

Kemp, Jerrold E. 1980. Planning \& Producing Audiovisual Materials. New York: Harper \& Row, Publishers.

Khadijah. 2015. Media Pembelajaran Anak Usia Dini. Medan: Perdana Publishing. 2016. Pengembangan Kognitif Anak Usia Dini. Medan: Perdana Publishing.

Sit, Masganti. 2012. Perkembangan Peserta Didik. Medan: Perdana Publishing.

Smaldino (et al). 2011. Instructional Technology and Media for Learning: (Teknologi Pembelajaran dan Media untuk Belajar). Jakarta: Kencana.

Sugiono. 2015. Metode Penelitian Kuantitatif, Kualitatif dan $R \&$ D. Bandung: Alfabeta.

Sutarman. 2009. Pengantar Teknologi Informasi. Jakarta: Bumi Aksara.

Sutirman. 2013. Media \& Model-model Pembelajaran Inovatif. Yogyakarta: Graha Ilmu. 